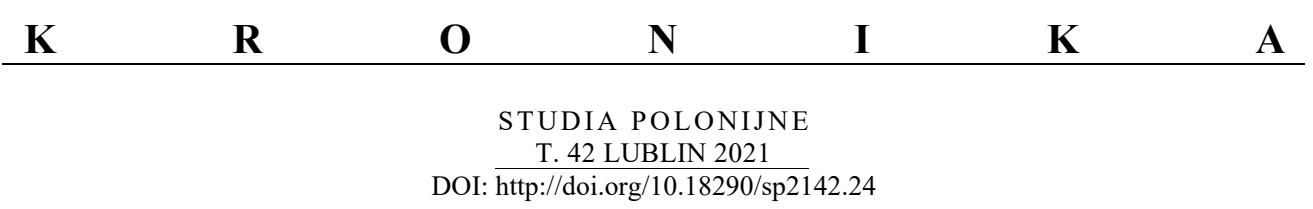

MARIA ANNA FURTAK

\title{
DZIAŁALNOŚĆ NAUKOWA OŚRODKA BADAŃ NAD POLONIĄ I DUSZPASTERSTWEM POLONIJNYM KUL ZA 2020 ROK
}

W roku 2020 Ośrodek funkcjonował w następującym składzie: dr hab. Jacek Gołębiowski, prof. KUL, ks. dr hab. Sławomir Zych, dr Paweł Sieradzki. Funkcję redaktora naczelnego „Studiów Polonijnych” pełnił ks. dr hab. Sławomir Zych. Stałym współpracownikiem Ośrodka była mgr Maria Anna Furtak, doktorantka Instytutu Historii KUL, sekretarz redakcji „Studiów Polonijnych".

\section{PROJEKTY BADAWCZE}

Pandemia COVID-19 znacznie utrudniła funkcjonowanie Ośrodka. Nie udało się zrealizować przewidzianego na ten rok projektu badawczego nad Polonią w Teksasie. Działalność Ośrodka skupiła się głównie na pracach w ramach grantu NPRH Polish Cathedrals - polskie dziedzictwo religijne, kulturowe, spoteczne i materialne w Stanach Zjednoczonych. Leksykon oraz kontynuacji projektu „Parafie i kościoły polskie w USA. Inwentaryzacja źródłowa i fotograficzna «Polish Cathedrals»" finansowanego przez Departament Współpracy z Polonią i Polakami za Granicą Kancelarii Prezesa Rady Ministrów. W ramach projektu inwentaryzacją objęto 18 polskich parafii na terenie stanu Illinois.

Pracownicy Ośrodka w 2020 r. prowadzili również badania w archiwach. Dr hab. Jacek Gołębiowski kontynuował kwerendę czasopism polonijnych w Bibliotece Towarzystwa Chrystusowego dla Polonii Zagranicznej w Poznaniu. Ks. dr hab. Sławomir Zych ukończył kwerendy w archiwach: archi-

Mgr MARIA ANNA FURTAK - doktorantka, Instytut Historii Katolickiego Uniwersytetu Lubelskiego Jana Pawła II; e-mail: furtakma@gmail.com. ORCID: https://orcid.org/0000-0002-4797-9135. 
diecezjalnym w Przemyślu, diecezjalnym w Rzeszowie oraz kilku archiwach podkarpackich parafii dotyczące opieki duszpasterskiej nad wychodźcami $\mathrm{z}$ tych terenów.

Ks. dr hab. Sławomir Zych wygłosił referat pt. „Mielczanie w kościelnym środowisku Przemyśla. Rekonesans badawczy” podczas konferencji „Miasto. Region. Ludzie. W 550. rocznicę lokacji miasta Mielca" zorganizowanej 14 listopada 2020 r. przez Muzeum Regionalne w Mielcu i Samorządowe Centrum Kultury w Mielcu. Brał również udział w projekcie „Zapytaj naszego eksperta" przygotowanym przez Uniwersytet Otwarty KUL dla maturzystów.

\section{PUBLIKACJE i DZIAŁALNOŚĆ WYDAWNICZA}

„Studia Polonijne” 41 (2020) (ss. $359+5$ nlb)

„Rocznik Kolbuszowski” 2020 (ss. $350+9$ nlb)

Roman Nir, oprac., Documentation of Polish parishes in the United States. Bibliography, vol. I: A-B / Dokumentacja polskich parafii w Stanach Zjednoczonych. Bibliografia, t. I: $A-B$, Chicago 2020.

Roman Nir, oprac., W.R.S. - N.C.W.C. Archiwum ks. prat. Rafała Gogolińskiego-Elston. Wybór źródet 1943-1948, t. I / W.R.S. - N.C.W.C. Archives of Rev. Msgr. Ralph Gogoliński-Elston. Selected sources 1943-1948, vol. I, Chicago-Rzeszów: Institute of the History and Archival Polonia; Bonus Liber 2020.

Roman Nir, oprac., W.R.S. - N.C.W.C. Archiwum ks. biskupa Stefana Woźnickiego. Wybór źródet 1944-1948, t. II / W.R.S. - N.C.W.C. Archives of Most Rev. Stephen S. Woźnicki. Selected sources 1944-1948, vol. II, ChicagoRzeszów: Institute of the History and Archival Polonia; Bonus Liber 2020.

Sławomir Zych, Na ojczystej i obcej ziemi. Książe Marcin Jerzy Lubomirski (1738-1800), Rzeszów-Kolbuszowa: Bonus Liber 2020.

W 2020 r. „Studia Polonijne” zostały włączone do indeksu czasopism naukowych European Reference Index for the Humanities and the Social Sciences (ERIH Plus).

Ks. dr hab. Sławomir Zych otrzymał nominację na redaktora naczelnego czasopisma naukowego „Resovia Sacra. Studia Teologiczno-Filozoficzne Diecezji Rzeszowskiej”. 